DOI: $10.1515 / \mathrm{rpp}-2017-0038$

$\mathrm{PhD}$ in Pedagogical Sciences, Associate Professor, IRYNA ANDROSHCHUK

Khmelnytskyi National University Address: 11 Instytutska St., Khmelnytskyi, 29016, Ukraine E-mail: lemen77@ukr.net

$\mathrm{PhD}$ in Pedagogical Sciences, Associate Professor, IHOR ANDROSHCHUK

Khmelnytskyi National University Address: 11 Instytutska St., Khmelnytskyi, 29016, Ukraine E-mail: lemen77@ukr.net

\title{
METHODOLOGY IN TRAINING FUTURE TECHNOLOGY AND ENGINEERING TEACHERS IN THE USA
}

\begin{abstract}
In the article, the defined problem has been justified and the significance of studying foreign experience in training future technology and engineering teachers in the USA has been determined. Particular attention has been paid to explanation of methods and forms of organization of future technology and engineering teachers' training in the USA. The authors have considered Education Technology Standards, developed by the International Society for Technology in Education (ISTE), that are used as reference points and determine the minimum amount of training as well as electives. In addition, there have been outlined such training techniques as microteaching, reflective teaching, the simulation method that allow involving the students into real teaching rather than role-playing; decrease complexity of pedagogical actions through ensuring acquisition of specific skills needed for the teacher in order to form experience of pedagogical interaction. It has been found out that in order to prove themselves during the first year of study in a higher education institution the students create their own web pages and portfolios that consist of working portfolio, showcase portfolio and documentation portfolio. It has been established that mini courses are actively used to help future technology and engineering teachers acquire necessary pedagogical skills. Based on analysis of the research findings, the authors have concluded that counseling or mentoring as forms of training greatly contribute to personal development of both students and their mentor as well as effective collaboration between school and university staff. It has been identified that enhancing effectiveness of teaching practice in American higher education institutions ensures involving clinical professors who monitor, guide and assess teaching practice of future specialists.
\end{abstract}

Keywords: technology and engineering teacher, pedagogical interaction, training methodology, disciplines, training methods, portfolio, microteaching, mentoring.

\section{INTRODUCTION}

Innovative processes taking place in education and integration into the European educational space require reconsideration of the approaches to professional training of specialists, including teachers. In the context of personality-oriented and competency-based educational paradigms and changes in school curricula, there appears to be a need to update methodology of training future handicraft and technology teachers using modern interactive methods and forms of training organization. The teacher, as stated in the new Ukrainian 
school concept, is to perform a new role "being not the only mentor and source of knowledge, but a coach, facilitator, tutor, moderator in the individual educational trajectory of the child" (Ministerstvo osvity i nauky Ukrainy, 2014). Therefore, the education process should not be aimed only at forming professional knowledge and skills; it is necessary to develop the teacher's personality and form their competences, which will ensure their selfrealization in personal and professional life. In this aspect, the study of the experience accumulated by foreign countries, in particular the United States, with regard to the methodology of future technology teachers' training, takes on special significance.

\section{THE AIM OF THE STUDY}

The aim of the study consists in generalizing US experience in training technology and engineering teachers, analyzing the main forms and methods for their implementation into Ukrainian education system

\section{THEORETICAL FRAMEWORK AND RESEARCH METHODS}

The results on analysis of psychopedagogical researches give an indication of a significant interest in the peculiarities of future teachers' training in other countries. Foreign researchers, namely, L. Darling-Hammond (1994), R. Floden \& J. Ferrini-Mundy (2001), A. Hartnett \& M. Naish (1980), S. Mau (1999), S. Wilson have studied the peculiarities of teacher training in the USA and, in particular, highlighted methods and forms of their training organization. Also it is necessary to note a small number of researches (by O. Halus, T. Kapeliushna, R. Monko, O. Orekhova, L. Shaposhnikova, O. Stelmashchuk, I. Zhernokleev) dedicated to the study of technology teachers' training abroad. These have become the basis for writing the article.

During theoretical study of the problem, we have used a set of such research methods as an explanatory-analytical method with the use of analysis and synthesis of scientific results on methodology of training future handicraft teachers; methods of generalization and systematization in order to highlight the peculiarities of methods and forms of teachers' professional training and formulation of conclusions.

\section{RESULTS}

In the United States, they pay significant attention to training of future technology and engineering teachers, as evidenced by the activities of an international organization titled the Council on Technology Teacher Education (n. a). Its main tasks are aimed at increasing the level of technology teachers' training by involving them in researches on technologies with an appropriate appointment of scholarships; introducing innovative ideas on their training and information provision.

Ball State University (Indiana), California University of PA, Millersville University (Pennsylvania), University of Wisconsin-Stout, the State University of New York at Oswego, Purdue University, etc. provide professional training of technology teachers.

T. Kapeliushna (2012) has studied the peculiarities of technology and engineering teachers' training in the USA by the example of Department of Technology at Ball State University (Indiana), which offers undergraduate programmes in Technology (pp. 35-36). According to the results, one can state that the programme is based on Education Technology Standards, developed by the International Society for Technology in Education (ISTE) and Indiana academic standards where the education institution is located; principles and standards justified by the The Interstate Teacher Assessment and Support Consortium (InTASC). It should be noted that all the standards are used as reference points and determine the minimum amount of technology teachers' training as well as electives. In middle, high or vocational schools graduates may teach technology disciplines, namely, 
Construction, Production, Communication, Transportation and obtain knowledge of the principles of learning and delivery of lessons, as well as practical experience of working with natural materials, power systems, robots, computers, etc. (Darling-Hammond, 1994; Mau, 1999). During training future technology teachers master the following disciplines: Architecture and Construction Technology, Manufacturing Technology, Design and Engineering Technology, Audio, Video and Digital Communication, Technology, Transportation, Distribution and Logistics Technologies. It is worthy of note that the names of courses as well as academic disciplines in the states may be somewhat different (Kapeliushna, 2012, pp. 37-38).

Widely practiced is microteaching, which consists of 1) reviewing relevant literature and preparation for a part of the lesson; 2) conducting a part of the lesson for three to five minutes with its video recording for schoolchildren or groupmates; 3 ) watching the video, its analysis and self-analysis. If necessary, the students can conduct the same part of the lesson again. After the students have gained some teaching experience, the time allotted for conducting a part of the lesson is increased to 20 minutes, so that future teachers may demonstrate the ability to interact with other participants of the education process. Microteaching as one of the main methods of learning is used in more than $91 \%$ programmes for teacher education in the USA. Its advantages include the involvement of the student into real teaching rather than role-playing; simplification of pedagogical actions through ensuring acquisition of specific skills; a favourable and supervised learning environment (Kapeliushna, 2012).

Mini courses are directed at assisting future teachers in obtaining pedagogical skills. Initially, they were offered to working teachers, but later began to be used by students. The implementation of mini courses is as follows: choosing a pedagogical skill needed to be developed or improved; reviewing relevant literature and performing certain exercises aimed at forming the skill; watching a video or a movie showing the skill in use, video tutorials; conducting a part of the lesson (from five to ten minutes) so that the skill may be applied, recording it on video; analyzing a fragment of the video. The use of mini courses allows the students to form the behavioural patterns needed in pedagogical activity.

The next method of training for pedagogical interaction in professional activity is reflective teaching. For this purpose, students are divided into groups of four to six. One of the members of the group acts as an "appointed teacher", who defines the aim and objectives of the lesson; plans and delivers the lesson; evaluates learning outcomes of their groupmates who act as pupils. Subsequently, a detailed discussion takes place that is expected to address actions and results of the appointed teacher. Reflective lessons should be interesting; their content should be original and differ from the academic programme; short (up to 15 minutes); the outcomes of the lesson should be analyzable and measurable (Halus, 2006; Kapeliushna, 2012).

To ensure the ability to interact during a discussion of a particular phenomenon in real life, one can use the simulation method, which involves listening to educational situations and stories from professors of pedagogy. Simulations provide a pedagogical problem in the context of a hypothetical classroom and generate several alternatives to solve it. The aim of simulation is to create an appropriate learning situation in which the typical behaviour of the student is formed using those methods and models of activity that experienced teachers consider to be relevant. Today, higher education institutions use computer simulations in teachers' training. For this, the student receives information about the pupils who are participants of the simulation and becomes familiar with the problems that need to be addressed. It must be noted that the simulation method is based on specific school situations, which also simulates and makes them take an active part in these situations. 
Thus, teacher training incorporates the technology of "partner teaching", that is, peer teaching.

In order to prove themselves during the first year of study in a higher education institution the students create their own web pages and electronic portfolios that are annually supplemented and are posted on the Internet. A portfolio contains photos and short autobiographical information written in an arbitrary manner; a description of their views and considerations regarding modern education: approaches, principles and technologies of learning. Covering their own views, the student can visualize them using videos, drawings, charts, tables, photographs, projects (Teacher Education Digital Portfolio, n. a). It allows the student to present not only their achievements, but also prove themselves as personality and a specialist with certain views on life, the education process and suggestions for its improvement.

The analysis of researches dedicated to the peculiarities of teacher training in the United States allows us to distinguish three main types of portfolios that are created during studies at a higher education institution as well as teaching practice at school: working portfolio, showcase portfolio (for display) and documentation portfolio.

Working portfolio reflects the student's learning outcomes and aims to demonstrate their progress during the training. It can contain information from parents and friends and allows teachers to certify and assess academic performance of a future teacher.

Showcase portfolio is based on the principle of an art collection, which shows the best works of the student. According to the results of this portfolio, a future teacher can publish a book, develop an interesting project, that is to prove themselves as a creative person. The student's daily pedagogical activity is not reflected in this type of portfolio, as they themselves decide what should be contained here.

Documentation portfolio often complements showcase portfolio. Both the teachers and students keep copies of the results of certification and assessment of the students' achievements, as well as the works the teachers assess. These records also become a part of working portfolio.

Counselling or mentoring is actively practiced during training of future teachers. Mentoring involves not only cooperation and interaction with the students; in fact, the role of "cognitive" mentor implies managing reflexive practice of future teachers. It contributes to personal development of both the student and their mentor. A successful way of mentoring is supportive interaction between school and university staff.

In order to increase effectiveness of teaching practice in the United States, higher education institutions hire "clinical professors", i.e. school teachers who are to supervise, manage and certify teaching practice. They do not have a degree, but occasionally they engage in teaching at school so that students can observe and discuss the education process (Hartnett, \& Naish, 1980).

The researches by O. Halus \& L. Shaposhnikov (2006) suggest that forming readiness of future technology teachers for pedagogical interaction in the USA is facilitated by personality-oriented approach, which is the basis for future teachers' training. In the education process, it is mainly realized through a democratic style of teaching: the student is considered as an equal participant in the education process; a partner who takes an active part in life of a higher education institution; the student's ideas on organization and implementation of the education process are taken into account; initiatives are welcomed. Of great importance are reflexive teaching and microteaching. All this contributes to training the students for pedagogical interaction in future professional activity.

It is worth mentioning the annual events aimed at activating technology teachers, which involve identification and rewarding: the best technology teacher for outstanding 
achievements in technology education (since 1950); the best programme of technology teachers' training; the best publication; the best research (Council on Technology Teacher Education Awards Programs, n. a). It promotes the teachers' creativity, stimulates them for personal and professional development.

\section{CONCLUSIONS}

Thus, having studied US experience in training future technology and engineering teachers, we came to the following conclusions:

1) the programme of training is based on Education Technology Standards, developed by the International Society for Technology in Education (ISTE) that are used as reference points and determine the minimum amount of training as well as electives; the students are actively involved in researches in technology with an appropriate appointment of scholarships; introduction of innovative ideas on their training and provision of necessary information resources; 2) the main methods and forms of training are microteaching, reflective teaching, the simulation method, mini courses, the portfolio method; 3) effectiveness of practical training is ensured by counselling or mentoring as well as involvement of clinical professors who supervise, manage and certify teaching practice.

The prospects for further studies are seen in analysis of the system of monitoring handicraft teachers' training abroad and identification of the main areas of diagnosing the level of specialists' training in the education system of Ukraine.

\section{REFERENCES}

1. Council on technology teacher education awards programs. (n. a). Retrieved from http://ctte.iweb.bsu.edu/awards/awards.html.

2. Council on technology teacher education. (n. a). Retrieved from http://ctte. iweb.bsu.edu/.

3. Darling-Hammond, L. (1994). Performance-based assessment and educational equality. II Harvard educational review, 62 (1), 5-26.

4. Halus, O. M., \& Shaposhnikova, L. M. (2006). Porivnialna pedahohika. Kyiv: Vyshcha shkola.

5. Hartnett, A., \& Naish, M. (1980). Technicians or social bandits? Some moral and political issues in the education of teachers. London: Croom Helm.

6. Kapeliushna, T. V. (2012). Profesiina pidhotovka vchyteliv trudovoho navchannia u SSHA. Suchasni informatsiini tekhnolohii ta innovatsiini metodyky navchannia u pidhotovtsi fakhivtsiv: metodolohiia, teoriia, dosvid, problemy, 31, 34-38.

7. Mau, S. C. (1999). The professional knowledge base for teaching: a philosophical justification for a plurality of ways of knowing. Montreal, QC: Concordia University.

8. Ministerstvo osvity i nauky Ukrainy. (2014). Kontseptsiia rozvytku osvity Ukrainy na period 2015-2025 rokiv. Vziato z http://old.mon.gov.ua/ua/pr-viddil/1312/ $1390288033 / 1414672797 /$.

9. Teacher education digital portfolio. (n. a). Retrieved from http://portfolio.iweb. bsu.edu/default.html.

10. Wilson, S., Floden, R., \& Ferrini-Mundy, J. (2001). Teacher preparation research: current knowledge, gaps, and recommendations. Retrieved from http://www. education.uw.edu/ctp/sites/default/files/ctpmail/PDFs/TeacherPrep-WFFM-02-2001.pdf. 